\title{
Evaluation of Contribution of Local Newspapers to Lifelong Learning (Example of Bartın Province)*
}

\author{
Elif Çuhadar ${ }^{1}$, Fatma Ünal, \\ ${ }^{1}$ Institute of Educational Sciences, Bartın University, Bartın, Turkey \\ ${ }^{2}$ Faculty of Education, Bartın University, Bartın, Turkey
}

Copyright $\bigcirc 2018$ by authors, all rights reserved. Authors agree that this article remains permanently open access under the terms of the Creative Commons Attribution License 4.0 International License

\begin{abstract}
In this study, while the definition of informal education, which displays the main features of lifelong learning, is made, it is also attempted to identify the contributions of the local newspapers, through which the society can reach its own unique and necessary information, to the lifelong learning of their readers. In the research, within this scope, it was aimed to evaluate the contributions of local newspapers to lifelong learning according to the opinions of the local newspaper readers in Bartin Province in Turkey. Among the mixed research patterns, converging parallel pattern was used in the research. The screening model was used in the quantitative research phase, and the phenomenological pattern was used in the qualitative research phase. As a result of the research, according to the opinions of the readers, about the contributions of local newspapers to life-long learning were found to be significantly different to gender, educational status, title and institution, local newspaper reading frequency and duration variables .In the study, it was concluded that the local newspapers were able to contribute to their readers' lifelong learning through the availability of limited opportunities and access to public institutions and employees, even at the point of insufficient education, health, environment, socio-cultural life, employment and labor news. To make more news in local newspapers on education, health, socio-cultural, environment and labor market and employment may contribute to lifelong learning.
\end{abstract}

Keywords Lifelong Learning, Informal Education, Newspaper, Local Newspaper, News, Reader

\section{Introduction}

While the physical boundaries of the world we know are constantly being renewed in unlimited change and development in the fields of science and technology, the concept of appropriate medium, time or climate, with the international meaning, as a means to the learning of individuals, brings to mind all kinds of interaction and learning materials that can be used together with the environment in which the people live. Today's societies, in which education and instruction cannot be confined to schools and classes only in an institutional sense, and lifelong learning is now a need and necessity, have had to re-examine the personal development of individuals and the needs of their communities and in parallel, lifelong learners have come to the forefront because it describes each situation as a phenomenon that will happen at any moment, rather than compressing learning into a field of life. Lifelong learning can also offer secondary opportunities and advanced learning opportunities in many ways while providing people with new experiences and learning opportunities [17].

The concept of learning is no longer solely a list of cognitive processes and learning characteristics created in the individual's mind. Learning is a clearer understanding and co-operation of all social, cultural, political, social, economic forces that together form and revitalize the learning platform [14]. When learning is thought to be a very comprehensive, flexible and constantly renewing and improving structure, its importance in life is more clearly perceived. Lifelong learning can be defined as a learning strategy that encompasses all purposeful learning activities, whether formal or informal, carried out continuously to develop knowledge, skills and competence [8].

The concept of lifelong learning is an important driving force for a person to be accepted in the society he lives, to take place as a qualified staff in the labor market in the economic sense, to psychologically fulfill himself, and to transmit his values, culture and renewed experience, when needed, to future generations, in order to ensure the continuity of the community.

There are various definitions of informal education which has a significant share in life-long learning. In UNESCO's Curriculum Terminology Dictionary (2013), three types of learning of lifelong learning are defined as 
follows:

"It refers to the formal education system of a self-contained country, realized as planned in private or public institutions, and vocational education, special education and some parts of adult education are also considered as parts of the formal education system. Nonformal education is a form of intentional and institutionalized education planned by an education provider. Nonformal education is an education method, which is additional to formal education in the lifelong learning process of the individuals, but outside formal education as a complementary education method. Informal education is a desired and conscious learning which is not institutional. It is an unorganized, unplanned form of education. It takes form as a social-based learning which is encountered in the family, at work, in the community, and in everyday life." Informal education can also include individual activities which can be done at home such as reading newspapers and books [18].

Experiential learning is a learning type qualified as a member of informal education [15]. This learning is not structured in terms of its objectives, learning time and/or learning support, may be intentional, but in most cases is unintentional, that is, accidental. Informal education is gradually becoming the validity key to lifelong learning policies. The purpose is to make visible the knowledge and experience, which are initially independent, to the full extent by the individual [9]. Unlike formal and non-formal education, in the natural accompaniment of life, it is not necessarily formal learning which is deliberately held. Sometimes it is not even noticed by people at that time, but it can settle in the memory as a life experience in the long term [4]. Informal education can play an active role in different areas of life, but in environments in which the same gains can be achieved, together with other people in the community and/or in developments which is available in the personal sense. In their study, Brody, Bangert and Dillon [5] have reached the following main activity areas and ranking content in which the differences related to informal education combine:

Business, Self-discipline, time management, education values, social interaction, empathy and planning.

Hobbies, Identity, self-expression, discipline, social interaction, independence, leadership;

Media and Information Technology; Visual

perception, hierarchical reasoning, communication skills, reading visual information, content

information;

Consumption; Personal expression, choices, identity, budgeting;

Peer, entertainment and family activities, sharing of perspectives, teamwork, and ability to take group decisions, communication, responsibility and tolerance.

Starting from the earliest periods of humanity, the desire of humans to reach and learn knowledge by wondering about the daily experiences has created today's press by using all the technological, economic and socio-cultural possibilities together with the development of the civilizations. The main function of the local newspaper is to inform the people about the happenings occurred in the place they live in. Despite their limited potentiality, local newspapers try to maintain this function. [6]. During the Renaissance period, developments that are of importance for the future related to education have become popular in the field of informal education. The basis of this is the invention of the printing press. The printing press has given the opportunity to take share from the field of idea development and cultural life to everyone who wants to learn by reaching and apply it to his life. Thanks to the printing press, knowledge was printed in books and brochures which were the local newspapers of the time, and all the people who wanted to access information were able to benefit from these privileges, which were once accessed by the wealthy people [3].

Although the local newspaper, which is one of the most important means of meeting the needs of individuals in their democratization adventure, regional development, education and training, socio-cultural development, and the development and maintaining of social structure, is not a school, it is culturally acquiring, socially adapting, illuminating, and in brief, lifelong teaching [20]. In order to document the importance of the use of newspapers and other communication organs in other countries of the world when considered as an element of lifelong learning, representatives of the world peoples gathered in Brussels on January $18^{\text {th }}$, 2011, realized the UNESCO Brussels conference, and concluded the conference by signing the "Brussels Declaration for Lifelong Communication Training" in line with the philosophy of "Lifelong Communication Training." The aim here is to establish and sustain a society where everyone can access, use and share news and information [2].

One of the means by which everyone can access news and information is local newspapers. In this study; the definition of the informal education that exhibits the main features of lifelong learning was made. The local newspapers, where the community can access the information they need, have been tried to identify the contributions of their readers to their lifelong learning through the informal education. In this context, it is based on the opinions of the local newspaper readers of Bartin Province in Turkey.

The sub-problems of the research for this purpose are as follows:

1. What are the opinions of readers about the contribution of local newspapers to lifelong learning?

2. Do the opinions of readers about the contribution of local newspapers to lifelong learning differ significantly according to the reading local 
newspapers (local newspaper reading frequency, newspaper reading duration)?

\section{Method}

\subsection{Research Model}

In the search it is tried to assess the contribution of local newspapers to lifelong learning according to the opinions of readers, and the converging parallel pattern was used among the mixed research methods. The mixed method research is a type of research in which combines the components of qualitative and quantitative research approaches (e.g., qualitative and quantitative perspectives, data collection, use of analysis and inference techniques) for the breadth and depth of understanding and validation. [10]. The aim of using mixed research pattern in the research is both to put forward the views of readers on local newspapers in general and to examine the readers' views on the subject in a more detailed and in-depth manner. The quantitative research phase of the study was used, which is research approaches that aim to describe a situation, which existed in the past or still exists, as it existed or still exists. The event, individual or object subject to the research is tried to be defined in its own conditions and as it is [11]. And in the qualitative research phase of the research, the phenomenological pattern was used. For studies that aim to investigate the phenomena, which are not unfamiliar to us but that we cannot fully comprehend, phenomenological pattern is an appropriate study pattern [21].

Participants The local newspaper readers in Turkey's Bartın Province are the universe of the study. However, it is difficult to determine all the newspaper readers and to reach them as well. Because of these difficulties, in determining the local newspaper readers, it was decided to collect data on institutions and organizations where the daily local newspapers were distributed regularly in 2016. It was attempted to determine both the accessible universe related to the readers of the research and the sample by applying the method of first determining these institutions and organizations and then determining the readers in the relevant institutions and organizations. The data belonging to the institutions and organizations making regular distribution of local newspapers were obtained by the researcher through collaboration with local newspapers, institutions and organizations. 811 local newspapers readers in these institutions and organizations were identified as the accessible universe of the research.

As some public institutions did not allow the data collection tools to be implemented in the research, these institutions were left out of the sample while determining the sample for readers for the research. It was decided to use a random sampling method in determining the sample for local newspaper readers related to the quantitative dimension of the research. It is useful to determine randomly when selecting similar objects that have similar distributions and variations with the same reasons in the universe that have equal variations [12]. The difficulty of reaching local newspaper readers and the fact that some public institutions did not allow research were the main reason for the selection of the random sample method in the determination of the sample for the readers of the research. 431 adults working in institutions and organizations under the sample, in which the local daily newspapers in Bartın Province were distributed, constituted the sample of the research. Distribution of the participants, who constitute the sample, according to their demographic characteristics is as follows:

Table 1. Demographic information of participants

\begin{tabular}{|c|c|c|c|}
\hline & & $\mathrm{f}$ & $\%$ \\
\hline \multirow{2}{*}{ Gender } & Female & 165 & 36,3 \\
\hline & Male & 288 & 63,4 \\
\hline \multirow{5}{*}{ Age } & $18-27$ & 47 & 10,4 \\
\hline & $28-37$ & 183 & 40,3 \\
\hline & $38-47$ & 180 & 39,6 \\
\hline & $48-57$ & 40 & 8,8 \\
\hline & 58 and above & 4 & 0,9 \\
\hline \multirow{5}{*}{$\begin{array}{c}\text { Education } \\
\text { Status }\end{array}$} & Primary education & 17 & 3,7 \\
\hline & High school & 62 & 13,7 \\
\hline & Associate Degree & 113 & 24,9 \\
\hline & Graduate & 224 & 49,3 \\
\hline & Postgraduate & 38 & 8,4 \\
\hline \multirow{2}{*}{ Title } & Civil Servant & 412 & 90,7 \\
\hline & Worker & 42 & 9,3 \\
\hline \multirow{6}{*}{$\begin{array}{c}\text { Institution } \\
\text { Worked }\end{array}$} & Governorate and Affiliated Institutions & 124 & 27,3 \\
\hline & University & 81 & 17,8 \\
\hline & Provincial Security Directorate & 84 & 18,5 \\
\hline & Municipality & 44 & 9,7 \\
\hline & Provincial Health Directorate & 66 & 14,5 \\
\hline & Provincial Directorate of National Education & 55 & 12,1 \\
\hline
\end{tabular}

In the qualitative dimension of the study, the criterion sampling method was used among the purposeful sampling methods in determining the readers to be interviewed. In order to resolve the research hypothesis, the researchers enter a sampling process, which includes the requirements such as determining the region, or location where the work will be done, and the number of participants to provide data [10]. Purposeful sampling methods are useful in exploring and explaining events and phenomena by studying them in depth in different situations. The basic concept of the criterion sampling method included in this method is to study all the cases belonging to a predetermined range of criteria by including them in the research. Here, the criterion concept or the criterion itself may be created by the researcher or a pre-prepared criteria list may be used [21]. In determining the readers to be interviewed; the 
criteria of being volunteer, reading the local newspaper, and employed in a public institution were used. In this context, a total of 42 people, with 18 females and 24 males working in public institutions and organizations in Bartın Province in Turkey were identified. Participants consisted of 5 females and 11 males from the Governorate and affiliated units; 2 females and 4 males from the Provincial Health Directorate; 3 females and 2 males from Provincial Security Directorate; 3 females and 2 males from Bartın University; 3 females and 2 males from the Provincial Directorate of National Education; and 2 females and 3 males from the Municipality.

\subsection{Data Collection Tools}

In the research, a questionnaire was prepared by the researchers for the contribution of local newspapers to lifelong learning for the purposes of the research. The questionnaire is defined as a means of gathering research and data from a series of questions in order to describe and design people's behavior and attitudes, beliefs, and the different conditions in life [7]. During the preparation of the questionnaire; literature scanning was performed, news on lifelong learning in daily local newspapers published in Bartın province were identified, six experts from the disciplines of lifelong learning and educational sciences related to the topic were interviewed, and a face to face study was held with these experts during the development stage of the questionnaire. The questionnaire constituted of three parts. In the first section, five questions related to the personal information about the participants (gender, age, education status, title and institution worked); in the second section, two questions to determine the local newspaper reading status of the participants (local newspaper reading frequency, newspaper reading duration); and in the third section, 41 items to determine the contribution of local newspapers to lifelong learning in terms of the participants were used, and ratings were given with a 5-point Likert scale. The survey, prepared together with the experts, was given the final form and the preliminary application was made to 78 persons from Bartın tradesmen of the subscribers of the five local newspapers published in the province of Bartın, who were not included in the sample. As a result of the preliminary application, the clarity of the questions and the items were tested, the results were re-presented to the opinion of the experts, and the reliability analysis was done. As a result of the analysis, Cronbach's Alfa Reliability Coefficient was 0.933. This value indicates that the reliability of the survey is high. As a result of all these expert opinions and analyzes, the questionnaire was given its final form. There were 30 articles on the questionnaire that was ready for actual application, and it was decided to use the triple Likert (I do not Agree, I Agree, I Partially Agree) in determining the opinions of the participants on the advice of the experts. The prepared questionnaire was applied in August 2016 with permission from the institutions covered by the sample.
A semi-structured interview form was prepared by the researcher to identify the readers' opinions on the contribution of local newspapers to lifelong learning. There are seven questions on the form prepared by obtaining expert opinion. The data were collected by individual interview technique. 42 interviewees were informed about the research topic and in-depth (drilling) questions were asked when necessary to better understand the questions when needed. The interviews were recorded with voice recorder device, and for participants who did not allow voice recording, theirs were done in writing. All participants were informed that their institution and identity information would be kept confidential. Each interview lasted an average of 30 minutes.

\subsection{Data Analysis}

Descriptive statistics were used in the analysis of the quantitative data collected by the questionnaire and SPSS 22.0 software was used for the analysis. Kolmogorov-Smirnov test was performed to determine whether the data were normally distributed and non-parametric tests were applied because the data were not normally distributed. The data with more than two variables were tested with the non-parametric Kruskal Wallis test, and Bonferroni correction was applied to determine among which groups the difference occurred. All the results obtained are presented in tables under the heading of findings.

The data obtained from the interviews in the study were analyzed by content analysis method. According to Yıldırım and Şimşek [21], the aim of content analysis is "to reach the concepts and relations that can explain the collected data." The content analysis of the data consists of the phases of writing the interview data, coding the data, finding the themes, and interpreting the findings. As a result of the interview made with 42 participants by the researcher, sound recordings/written documents were resolved. In the texts obtained, words and phrases were defined, the meanings which may be implicit in them were examined in depth, and it was tried to describe the expressions. A list of encodings was created taking into account all the answers given by the participants for each interview question on the contribution of local newspapers to lifelong learning. The themes were determined taking into account the differences and similarities of the answers and their relationship with each other. In order to provide a high level of validity of the research, all examined texts were analyzed. In addition, direct quotations were made from the replies of participants (K1, K2 ...).

\section{Findings}

\subsection{Findings Related to the First Subproblem}

Analyzes for the first subproblem of "What are the opinions of readers about the contribution of local 
newspapers to lifelong learning?" were presented in order.

The results related to the answers given by the participants to the question "Why do you read local newspapers? Please explain," are shown in Table 2 according to the themes.

Table 2. The distribution of the responses given to the question "Why do you read local newspapers? Please explain" according to the themes

\begin{tabular}{|c|c|c|}
\hline Theme & Frequency & Descriptions related to Coding \\
\hline \multirow{4}{*}{$\begin{array}{c}\text { Why do you } \\
\text { read local }\end{array}$} & 35 & To get information about our region and our city. \\
\cline { 2 - 3 } newspapers? & 7 & To follow news about the institution I work for. \\
\cline { 2 - 3 } $\begin{array}{c}\text { Please } \\
\text { explain }\end{array}$ & 1 & To get information in general terms. \\
\cline { 2 - 3 } & 1 & As it is my habit to read. \\
\cline { 2 - 3 } & 1 & To be aware of cultural and social activities. \\
\hline
\end{tabular}

In Table 2, the participants were asked the question "Why do you read local newspapers? Please explain" and 35 participants described the reasons for reading local newspapers as "to get information about our region and our city". In addition, as all of the participants were working in a public institution, their second answer was "to follow news about the institution I work for". 7 participants said "I read in order to get information in general terms". In addition to the above reasons, some participants gave their answers as "it is my habit to read, to be aware of cultural and social activities, and to spend time". The following statements are examples of responses given by the participants to this question:

- "I read to follow the news, changes and developments in our province." (K13)

-"Since it is possible to get information about my city and to learn the information and news we cannot hear from the people we communicate with." (K35)

- "I read to be aware of the city I live in. I think if we live here we should be aware of what's going on, because we do not find everything going on here in national newspapers." (K41)

The results of the responses to the question "How many local newspapers do you read per day?" asked to the participants are shown in Table 3 according to the themes.

Table 3. The distribution of the responses given to the question "How many local newspapers do you read per day?" according to the themes

\begin{tabular}{|c|c|c|}
\hline Theme & Frequency & Descriptions related to Coding \\
\hline \multirow{2}{*}{$\begin{array}{c}\text { How many local } \\
\text { newspapers do you } \\
\text { read per day? }\end{array}$} & 15 & I read 1 local newspaper. \\
\cline { 2 - 3 } & 13 & I read 2 local newspapers. \\
\cline { 2 - 3 } & 4 & I read 5 local newspapers. \\
\cline { 2 - 3 } & 1 & I read 3 local newspapers. \\
\hline
\end{tabular}

In Table 3, participants were asked "How many local newspapers do you read per day?" to which 15 participants responded as once a day, 13 participants 2 times a day, while the number of participants who read all of the 5 local newspapers published in Bartın province was 9. 4 participants read 3 local newspapers a day, 1 person read 4 local newspapers a day, and it is understood that all of the participants surely read local newspapers even if at least once a day. The following statements are examples of responses given by the participants to this question:

-"I usually follow two of them."(K41)

-"I am fortunate enough to read at least three local newspapers per day for my work."(K40)

-“I surely read a local newspaper.”(K28)

-"I read 4 local newspapers."(K27)

-"I read all of the 5 newspapers."(K18)

The results related to the responses given to the question "Do you think that local newspapers provide continuity of a knowledgeable community open to learning?" asked to the participants are shown in Table 4 according to the themes.

Table 4. The distribution of the responses given to the question "Do you think that local newspapers provide continuity of a knowledgeable community open to learning? Can you give examples?" according to the themes

\begin{tabular}{|c|c|c|c|c|}
\hline Theme & Frequency & Responses & Frequency & Descriptions related to Coding \\
\hline \multirow{11}{*}{$\begin{array}{l}\text { Do you think that local } \\
\text { newspapers provide continuity } \\
\text { of a knowledgeable } \\
\text { community open to learning? } \\
\text { Can you give examples? }\end{array}$} & \multirow{7}{*}{22} & \multirow{7}{*}{ Yes, I think so. } & 11 & Environment and nature news \\
\hline & & & 9 & News about the history of Bartın \\
\hline & & & 7 & Health news \\
\hline & & & 7 & Educational news \\
\hline & & & 6 & Socio-cultural news \\
\hline & & & 2 & Labor and employment news \\
\hline & & & 2 & Plan-project news related to the Province \\
\hline & \multirow{3}{*}{11} & \multirow{3}{*}{ No, I do not think so. } & 3 & The advertising anxiety of newspapers \\
\hline & & & 2 & The inadequacy of the content of newspapers \\
\hline & & & 1 & The ignorance of the makers of news \\
\hline & 9 & I partially think so. & & \\
\hline
\end{tabular}


In Table 4, the participants were asked the question "Do you think that local newspapers provide continuity of a knowledgeable community open to learning? Can you give examples?" and while 22 participants said "Yes, I think so," 11 participants gave environment and nature news, 9 participants news about the history of Bartın, 7 participants health news, again 7 participants educational news, 6 participants socio-cultural news, 2 participants labor and employment news, and 2 participants plan-project news related to the Province as an example. 11 participants said "No, I do not think so." And as reasons for not thinking so, 3 participants told the advertising anxiety of newspapers, 2 participants the inadequacy of the content of newspapers, 1 participant the ignorance of the makers of news, and 1 participant the majority of political news. Generally, it can be seen that the opinion that local newspapers provide continuity of a knowledgeable community open to learning is accepted. The following statements are examples of responses given by the participants to this question:

-"I think it's important. I think that society is constantly informed as the public, social, cultural, educational and health related activities in our province are published. I follow the information about construction of nuclear power plant and HEPP and I am informed."(K1)

-"I think so. Especially, the news about the history of Bartın draws my attention. They also show the young generation the development process of Bartın.'(K27) -"I certainly think so, because there are events to be held in the province on local newspapers. We are aware of cultural activities. They also feature descriptive texts about the natural beauty of our region. We have a lot of information about the city we live in, especially based on past years."(K41)

-"I think so. We can at least have knowledge of current news. If our people know something wrong, they can be informed with the right information. For example, thanks to the right news about seasonal vaccinations, our people are now vaccinated."(K8)

-"I certainly think so. What matters most is that they give reading habits and contribute to society's continued readership. They provide a socio-cultural development. For example, they regularly inform about book fairs, authors, exhibitions."(K38)

The results of the responses to the question "Which of the news in local newspapers attract your interest most?" asked to the participants are presented in Table 5 according to the themes.

In Table 5, the participants were asked the question "Which of the news in local newspapers attract your interest most?" 19 participants answered this question as "investment, plan-project news about the city interest me mostly," 10 participants as "socio-cultural news," 9 participants as "environmental news," 8 participants as "news on public order-court cases," 7 participants as "health news," 6 participants as "educational news," 5 participants as "columns," 1 participant as "labor market and employment news," and 1 participant as "A certain topic does not interest me."

Table 5. The distribution of the responses given to the question "Which of the news in local newspapers attract your interest most?" according to the themes

\begin{tabular}{|c|c|c|}
\hline Theme & Frequency & Descriptions related to Coding \\
\hline \multirow{4}{*}{\begin{tabular}{c} 
Which of the \\
news in local \\
newspapers \\
\cline { 2 - 3 } $\begin{array}{c}\text { attract your } \\
\text { interest } \\
\text { most? }\end{array}$
\end{tabular}} & 19 & Investment, plan-project news about the city \\
\cline { 2 - 3 } & 7 & Socio-cultural news \\
\cline { 2 - 3 } & 6 & Environmental news \\
\cline { 2 - 3 } & 5 & Hews on public order-court cases \\
\cline { 2 - 3 } & 1 & Labor market and employment news \\
\cline { 2 - 3 } & 1 & A certain topic does not interest me \\
\hline
\end{tabular}

The results of the participants' responses to the question "Why?" are shown in Table 6 according to the themes.

Table 6. The distribution of the responses given to the question "Which of the news in the local newspapers interest you most? Why?" according to the themes

\begin{tabular}{|c|c|c|}
\hline Theme & Frequency & Descriptions related to Coding \\
\hline \multirow{9}{*}{ Why? } & 12 & $\begin{array}{c}\text { Plans and projects are important for a city's } \\
\text { future. }\end{array}$ \\
\hline & 10 & $\begin{array}{l}\text { Socio-cultural, educational news are important } \\
\text { for the development of society. }\end{array}$ \\
\hline & 6 & $\begin{array}{l}\text { To be informed about what is going on where I } \\
\text { live. }\end{array}$ \\
\hline & 3 & $\begin{array}{l}\text { To learn about different human experiences in } \\
\text { the columns. }\end{array}$ \\
\hline & 3 & The security of the city I live in is very important. \\
\hline & 2 & $\begin{array}{l}\text { I live in this city and environmental news are } \\
\text { important. }\end{array}$ \\
\hline & 2 & $\begin{array}{l}\text { To gain experience after the events I am } \\
\text { informed about. }\end{array}$ \\
\hline & 2 & For my personal development, family and circle. \\
\hline & 1 & $\begin{array}{l}\text { Employment news are important for the } \\
\text { elimination of unemployment in my city. }\end{array}$ \\
\hline
\end{tabular}

In Table 6, the participants were asked the question "Which of the news in the local newspapers interest you most? Why?" While 12 participants answered this question as "Plans and projects are important for a city's future" with the most frequency, 10 participants answered as "Socio-cultural, educational news are important for the development of society." 6 participants answered as "to be informed about what is going on where I live," 3 participants as "to learn about different human experiences in the columns," again 3 participants as "the security of the city I live in is very important," 2 participants as "I live in this city and environmental news are important," 2 participants as "to gain experience after the events I am informed about," 2 participants as "for my personal development, family and circle," and 1 participant as "Employment news are important for the elimination of 
unemployment in my city." The following statements are examples of responses given by the participants to this question:

-"All the news contributing to the development of our province attracts my attention. Investment news in particular because every investment made in Bartın avoids immigration and ensures the development of our province."(K33)

-"Institutional activities and health news are the most noticeable news for me. For example, the activities of the municipality attract my attention because the physical development of the city is also important."'(K31)

-"They do not attract my attention much because you can see the same news over a few days."(K29)

-"Socio-cultural and health news attract my attention in terms of personal development, and investment and project news in general.'(K14)

-"Rather investment, employment and labor news attract my attention. I think the reason for this is that they contribute to the development of my city."(K13)

The results of the responses to the question "Do you find the health, education, socio-cultural, environmental, labor market and employment news given in local newspapers sufficiently educating and informative?" asked to the participants are shown in Table 7 according to the themes.

Table 7. The distribution of the responses given to the question "Do you find the health, education, socio-cultural, environmental, labor market and employment news given in local newspapers sufficiently educating and informative?" according to the themes

\begin{tabular}{|c|c|c|}
\hline Theme & Frequency & $\begin{array}{c}\text { Descriptions related } \\
\text { to Coding }\end{array}$ \\
\hline \begin{tabular}{c} 
Do you find the health, \\
education, \\
socio-cultural, \\
environmental, labor \\
market and \\
\cline { 2 - 3 } employment news \\
given in local \\
newspapers \\
sufficiently educating \\
and informative?
\end{tabular} & 17 & $\begin{array}{c}\text { I find them partially } \\
\text { sufficient. }\end{array}$ \\
\hline
\end{tabular}

In Table 7, 17 participants found the news in local newspapers "partly sufficient," while 13 participants answered as "I find them sufficient," and 12 participants as "I do not find them sufficient." It is understood that the total number of those who found them partly sufficient is more than that of those who did not find them sufficient.

The results of the responses to the question "If you find them sufficient, what do they give you?" asked to the participants as the continuation of the same question are shown in Table 8 according to the themes.

In Table 8, the question "If you find them sufficient, what do they give you?" was asked to the participants, and 9 participants said "My circle and family gain from the news related to health," again 9 participants said "I get personal gain when I learn things that I do not know," 8 participants said "It contributes to the development of the city and people together," 5 participants said "Educational news provide personal gain," and 5 participants said "Labor-employment news provide gain to the unemployed people around me." 4 participants answered the question as "Socio-cultural news contributes to my socialization," and 2 participants as "Knowing everything that happens in my city provides me gain." The following statements are examples of responses given by the participants to this question:

-"The news on these topics is usually enough. I do not see any lack of information. It can be a sign of the city's development. Of course we can also see requests for the city. We have the chance to evaluate the education, socio-cultural and health news. For example, a women's day conference was written descriptively for those who could not attend the conference, and many citizens could read."(K5)

-"I follow the health, education, socio-cultural, environment, labor market and employment news. Education contributes individually. I follow the labor market to help my unemployed friends who need a job."(K7)

-"I find all the correct news about all the news to be educating and informative.”(K10)

-"I do not find them sufficient. I have not seen much that comprehensive articles were written in this matter. They give the news superficially, but there is no continuation. There is some in some topics such as health and employment, but not much in educational, socio-cultural and environmental topics. For example, I had read news about the ways to protect from flu in health topic, and I had applied it.”(K11)

Table 8. The distribution of the responses given to the question "If you find them sufficient, what do they give you?" according to the themes

\begin{tabular}{|c|c|c|}
\hline Theme & Frequency & $\begin{array}{c}\text { Descriptions related to } \\
\text { Coding }\end{array}$ \\
\hline \multirow{7}{*}{$\begin{array}{l}\text { If you find them } \\
\text { sufficient, what do } \\
\text { they give you? }\end{array}$} & 9 & $\begin{array}{l}\text { My circle and family gain } \\
\text { from the news related to } \\
\text { health. }\end{array}$ \\
\hline & 9 & $\begin{array}{l}\text { I get personal gain when I } \\
\text { learn things that I do not } \\
\text { know. }\end{array}$ \\
\hline & 8 & $\begin{array}{l}\text { It contributes to the } \\
\text { development of the city and } \\
\text { people together. }\end{array}$ \\
\hline & 5 & $\begin{array}{c}\text { Educational news provides } \\
\text { personal gain. }\end{array}$ \\
\hline & 5 & $\begin{array}{l}\text { Labor-employment news } \\
\text { provides gain to the } \\
\text { unemployed people around } \\
\text { me. }\end{array}$ \\
\hline & 4 & $\begin{array}{l}\text { Socio-cultural news } \\
\text { contributes to my } \\
\text { socialization. }\end{array}$ \\
\hline & 2 & $\begin{array}{l}\text { Knowing everything that } \\
\text { happens in my city provides } \\
\text { me gain. }\end{array}$ \\
\hline
\end{tabular}


The results of the responses to the question, "Do you prefer local newspapers to receive health, education, socio-cultural, environmental, labor market and employment news in your area? Why?" asked to the participants, are shown in Table 9 according to the themes.

In Table 9, the participants were asked the question "Do you prefer local newspapers to receive health, education, socio-cultural, environmental, labor market and employment news in your area? Why?" and 25 participants denoted that they preferred local newspapers while 14 participants denoted that they partly preferred and 3 participants said that they did not prefer. Although a part of the participants partly prefer, it is understood that a majority of them prefer local newspapers to receive health, education, socio-cultural, environmental, labor market and employment news. Again, when their reasons for preference were asked, 22 participants answered as "I can receive all kinds of news related to where I live," while 11 participants answered as "National newspapers do not give news about my city," 6 participants as "I learn the news about the advancement and development of the city," and 6 participants as "I find them easily accessible everywhere and on time." And 2 participants said "They are important for my personal development." The following statements are examples of responses given by the participants to both of these questions:

-"I prefer to learn all about Bartın from my local newspaper. All in all, national newspapers cannot provide what has happened locally. I also have access to local newspapers in many places I go to, such as cafes, pastry shops."(K2)

-"Yes I do. Because, in general, such news are rare in the national press, and not detailed. But the local newspapers have more detailed information."(K5) -"Yes I prefer. For example, how is the region affected in development? I prefer the local newspapers in matters such as population status, unemployment and employment status, and educating and non-political columns."(K10)

-"No, I do not prefer. Because I do not think they are sufficient. There should be more. But I happen to be informed by chance when I read them."(K32)

Table 9. The distribution of the responses given to the question "Do you prefer local newspapers to receive health, education, socio-cultural, environmental, labor market and employment news in your area? Why?" according to the themes

\begin{tabular}{|c|c|c|c|c|}
\hline Theme & Frequency & Responses & Frequency & Descriptions related to Coding \\
\hline \multirow{2}{*}{$\begin{array}{c}\text { Do you prefer local } \\
\text { newspapers to receive } \\
\text { health, education, } \\
\text { socio-cultural, } \\
\text { environmental, labor } \\
\text { market and employment } \\
\text { news in your area? }\end{array}$} & 25 & Yes, I do. & 22 & $\begin{array}{c}\text { I can receive all kinds of news related to where } \\
\text { I live }\end{array}$ \\
\cline { 3 - 5 } & 14 & I partially do. & 6 & $\begin{array}{c}\text { National newspapers do not give news about } \\
\text { my city }\end{array}$ \\
\cline { 2 - 5 } & 3 & No, I do not. & 2 & $\begin{array}{c}\text { I learn the news about the advancement and } \\
\text { development of the city }\end{array}$ \\
\cline { 2 - 5 } & & & $\begin{array}{c}\text { They are important for my personal } \\
\text { on time }\end{array}$ \\
\hline
\end{tabular}

The results of the responses to the question "What kind of educational information in local newspapers do you think gives you a lifelong learning experience? Also, what are their contributions to your learning process in life? Please explain," asked to the participants are shown in Table 10 according to the themes.

Table 10. The distribution of the responses given to the question "What kind of educational information in local newspapers do you think gives you a lifelong learning experience? Also, what are their contributions to your learning process in life? Please explain" according to the themes

\begin{tabular}{|c|c|c|c|c|}
\hline Theme & Frequency & Responses & Frequency & Descriptions related to Coding \\
\hline \multirow{6}{*}{$\begin{array}{l}\text { What kind of educational } \\
\text { information in local } \\
\text { newspapers do you think } \\
\text { gives you a lifelong learning } \\
\text { experience? Also, what are } \\
\text { their contributions to your } \\
\text { learning process in life? } \\
\text { Please explain. }\end{array}$} & \multirow{2}{*}{28} & \multirow{2}{*}{$\begin{array}{l}\text { I think they provide } \\
\text { gain. }\end{array}$} & 21 & $\begin{array}{l}\text { Every informing and educating news I read } \\
\text { can give lifelong experience. }\end{array}$ \\
\hline & & & 5 & $\begin{array}{l}\text { There is the function of contribution to } \\
\text { people's lifelong learning inherent in the local } \\
\text { newspapers' nature. }\end{array}$ \\
\hline & \multirow{2}{*}{9} & \multirow{2}{*}{$\begin{array}{l}\text { I think they provide } \\
\text { partial gain. }\end{array}$} & 3 & $\begin{array}{l}\text { Local newspapers provide polyphonic } \\
\text { learning. }\end{array}$ \\
\hline & & & 2 & $\begin{array}{l}\text { Critical news help us to develop ourselves by } \\
\text { demonstrating our deficiencies. }\end{array}$ \\
\hline & \multirow{2}{*}{5} & \multirow{2}{*}{$\begin{array}{l}\text { I do not think that they } \\
\text { provide gain }\end{array}$} & 4 & $\begin{array}{l}\text { I find local newspapers insufficient and } \\
\text { superficial. }\end{array}$ \\
\hline & & & 1 & $\begin{array}{l}\text { The pages of local newspapers are rather full } \\
\text { of advertisements. }\end{array}$ \\
\hline
\end{tabular}


In Table 10, the participants were asked the question "What kind of educational information in local newspapers do you think gives you a lifelong learning experience?" and 28 participants denoted that they gave lifelong learning experience to them. While 9 participants thought that they gave partial experience, 5 participants told that they gave no lifelong learning experience. And as a response to the question "Also, what are their contributions to your learning process in life? Please explain," 21 participants said "Every informing and educating news I read can give lifelong experience," with the highest frequency number. With the second highest frequency number, 17 participants denoted that "The news I read contributes to my life by teaching me what I do not know." 5 participants said "There is the function of contribution to people's lifelong learning inherent in the local newspapers' nature," 3 participants said "Local newspapers provide polyphonic learning," and 2 participants said "Critical news help us to develop ourselves by demonstrating our deficiencies." 4 participants, who did not think that they provided lifelong learning experience, answered this question as "I find local newspapers insufficient and superficial," and 1 participant said "The pages of local newspapers are rather full of advertisements." The following statements are examples of responses given by the participants to both of these questions:
-"The media needs to provide health, education, employment, socio-cultural information and news for the lifelong learning community somewhere in local newspapers. The learners have no age and human experiences should be written so that people learn. As a careful reader, I think local newspapers contribute to my learning process."'(K3)

-"Yes, I think they give a lifelong experience with certain news. I find articles about Bartın's history and news about Bartın's discoveries educating, informative and contributing."(K6)

-"Every news that I believe to be beneficial to health, education, the environment and all other topics gives lifelong learning experience. In life, I can apply to my own life. For example, I have been aware of this issue and have been more careful since I read about the current in the sea."(K38)

-"I can say that the contribution of local newspapers in Bartın province to my learning process is limited. Very little educational news. Of course, they also contribute, but not enough."(K33)

The results of the responses to the question "Do you share the information and news you learn from local newspapers with your family and friends? What news do you share the most? Explain it by example," asked to the participants are shown in Table 11 according to the themes.

Table 11. The distribution of the responses given to the question "Do you share the information and news you learn from local newspapers with your family and friends? What news do you share the most?" according to the themes

\begin{tabular}{|c|c|c|c|c|}
\hline Theme & Frequency & Descriptions related to Coding & Frequency & Descriptions related to Coding \\
\hline \multirow{9}{*}{$\begin{array}{l}\text { Do you share the } \\
\text { information and news you } \\
\text { learn from local newspapers } \\
\text { with your family and } \\
\text { friends? What news do you } \\
\text { share the most? }\end{array}$} & \multirow{5}{*}{36} & \multirow{5}{*}{ I always share. } & 20 & I share health news. \\
\hline & & & 16 & I share educational news. \\
\hline & & & 15 & I share socio-cultural news. \\
\hline & & & 9 & $\begin{array}{c}\text { I share labor and employment } \\
\text { news. }\end{array}$ \\
\hline & & & 9 & $\begin{array}{l}\text { I share investment and } \\
\text { plan-project news. }\end{array}$ \\
\hline & \multirow{3}{*}{5} & \multirow{3}{*}{ I partially share } & 5 & I share environmental news. \\
\hline & & & 4 & I share all news. \\
\hline & & & 3 & $\begin{array}{l}\text { I share the news related to } \\
\text { interesting human experiences. }\end{array}$ \\
\hline & 1 & I never share & 1 & $\begin{array}{l}\text { I do not find them credible and } \\
\text { reliable. }\end{array}$ \\
\hline
\end{tabular}


In Table 11, the participants were asked the question "Do you share the information and news you learn from local newspapers with your family and friends?" and 36 participants denoted that they shared this information with their close circle. While 5 participants thought they shared partially, 1 participant told that he did not share anything. And as a response to another question "What news do you share the most? Explain it by example," 20 participants said "I share health news" with the highest frequency number. With the second highest frequency number, 16 participants said "I share educational news." 15 participants said "I share socio-cultural news," 9 participants said "I share labor and employment news," and 9 participants said "I share investment and plan-project news". The following statements are examples of responses given by the participants to both of these questions:

-"I read local newspapers and take them home and share them with my family. I share mostly corporate, health and environmental news. For example, with the information I got about the flu vaccine that we needed in the winter season, we had flu vaccination with all my family, and benefitted from it.”(K5)

-"Since all the valuable information I learn from the local newspapers enter in my house, I certainly share it with my family and friends. For example, I especially share the labor market and employment news with my friends who want to have a job.
Therefore, I think that I contribute to the evaluations of my unemployed friends with high education levels to prevent their migration from the city if their criteria fit."(K7)

-"Yes, I share. Usually, I share news about events, activities the municipality will hold, plans, and projects. For example, when a theatre group arrives in our Province, I inform my family, and we go and watch them."'(K8)

-"I share them. I share health and education news that can be shared. For example, I read a news about the children's anxiety related to exam, and shared it with both my wife and my soon-to-be-tested child."(K21) -"Yes, I definitely share. I share health, education, socio-cultural news rather with my family, and news about my institution with my friends. For example, I had read that a new private education institution that offered English courses was active. I attended that course myself for some time."(K32)

\subsection{Findings Related to the Second Research Problem}

The Kruskal Wallis test was conducted to determine whether the opinions of readers about the contribution of local newspapers to lifelong learning differed significantly according to the frequency of reading local newspapers and the results are shown in Table 12.

Table 12. Kruskal Wallis test results of the opinions of readers about the contribution of local newspapers to lifelong learning by the frequency of reading local newspapers

\begin{tabular}{|c|c|c|c|c|c|}
\hline Reading frequency & $\mathbf{N}$ & Rank Average & $\mathbf{x}^{\mathbf{2}}$ & $\mathbf{P}$ & Binary Comparisons \\
\hline Everyday & 131 & 237.50 & 7.47 & $0.02 *$ & * Every day and every month \\
\hline Once a week & 141 & 216.99 & & & \\
\hline Once in a month & 159 & 197.41 & & & \\
\hline None & - & - & & & \\
\hline
\end{tabular}

As seen in Table 12, there is a significant difference in the readers' opinion on the contribution of local newspapers to lifelong learning according to the frequency of reading local newspapers $\left[X_{(3)}^{2}=7.47 ; \mathrm{p}<0.05\right]$. Bonferroni correction was applied to determine which groups differed significantly. As a result of the comparisons made, it was determined that there is a significant difference between those with the frequency of reading local newspapers as "Everyday" and "Monthly" ( $\mathrm{U}=8455 ; \mathrm{p}<0.017)$, and this difference was in favor of those who read "Everyday".

The Kruskal Wallis test was conducted to determine whether the opinions of readers about the contribution of local newspapers to lifelong learning differed significantly according to the duration of reading newspapers and the results are shown in Table 13.

Table 13. Kruskal Wallis test results of the opinions of readers about the contribution of local newspapers to lifelong learning by the duration of reading newspapers

\begin{tabular}{|c|c|c|c|c|c|}
\hline Daily time & $\mathbf{N}$ & Rank Average & $\mathbf{x}^{\mathbf{2}}$ & $\mathbf{P}$ & Binary Comparisons \\
\hline Less than an hour & 355 & 204.44 & 18.02 & $0.00 *$ & * Less than one hour and One hour \\
\hline One hour & 71 & 273.07 & & & \\
\hline Two hours & 5 & 226.30 & & & \\
\hline More than two hours & & & & & \\
\hline
\end{tabular}


As seen in Table 13, there is a significant difference in the opinions of readers about the contribution of local newspapers to lifelong learning according to the duration of daily newspaper reading $\left[X_{(3)}^{2}=18.02 ; \mathrm{p}>0.05\right]$. Bonferroni correction was applied to determine which groups differed significantly. As a result of the comparisons made, it was determined that there was a significant difference between those who read local newspapers daily "Less than an hour" and "One hour" $(\mathrm{U}=8598.5 ; \mathrm{p}<0.017)$ and this difference was found to be in favor of those who read "One hour".

\section{Conclusions}

There is a significant difference in the opinions of readers about the contribution of local newspapers to lifelong learning according to the frequency of reading local newspapers in the research. There is a significant difference between those with a frequency of reading local newspapers as "Everyday" and "Monthly", and it is determined that this difference is in favor of those who read "Everyday". At this point, it can be said that the tendency to read the local newspapers is high because they are delivered to the public institutions where the research is conducted on a regular basis and the readers can access the local newspaper for free.

As a result of the comparisons made according to the reading period, it is understood that there is a significant difference between those who read local newspapers daily for "Less than an hour" and for "One hour", and that this difference is in favor of those who read for "One hour". The page numbers of local newspapers reaching public institutions range from 8 to 9 . It is seen that the number of local newspapers published daily in Bartın province of Turkey is five and adults working in public institutions and organizations are trying to read all of these newspapers.

Participants in the research explained the reason for reading local newspapers as to get news about the city and region they live in. Local newspapers seem to fulfill the obligation to inform the city as one of its main purposes. In research conducted by Akyüz [1] on the history of local newspapers, it was understood that all the news belonging to the city and its environment affected the society, and that the Konya Vilayet newspaper was almost as educational as a school and gave critical news. The results of this research show that the leading reason for reading local newspapers is that they give more detailed information about the local place.

In their answer to the question "How many local newspapers do you read per day?", it was determined that most of the participants read at least one or two local newspapers. The fact that local newspapers regularly reach the public institutions and that the employees have the opportunity to read it can be seen as the most important reason for achieving this result.

When asked "Do you think local newspapers provide continuity of a knowledgeable community open to learning? Can you give examples?", the majority of the participants gave the answer "Yes, I think so". In this regard, they indicated that the environmental pollution and nature news, and news about Bartın's history, health, education, workforce and employment were influential. In a similar study made by Schönbach et al. [16] in the Netherlands; as a result of the research on the effectiveness of informing and communicating information between online and printed newspapers, it has been seen that many news are influential in the light of the information given by visual and printed newspapers in the sense of informing and educating the people, and it has been understood that the daily print media is more permanent and effective. Some respondents gave the answer "No, I do not think so" to this question, indicating that the reason for this is that local newspapers have advertising anxiety and lack of content. In general, it is understood that local newspapers can help to ensure the continuity of the knowledgeable community open to learning.

When asked "Which of the news in the local newspapers interest you most? Why?", the vast majority of participants told that as they thought that the plans and projects were important for the future of the city, investments and projects about the city, the socio-cultural news that emphasizes the importance of cultural development and education of the community as well as the environmental and health news that their readers thought they could implement in their lives interested them. MacDonald and Hoffman-Goetz [13] concluded in their research that local newspapers provided more detail and information than other media related to rural community health news.

When asked "Do you find the health, education, socio-cultural, environmental, labor market and employment news given in local newspapers sufficiently educating and informative? If you do, what do they give you?", the participants answered "I find them partially sufficient and sufficient" at a high level. While indicating that especially the health news in local newspapers provided gains in terms of environment and family and that provided personal gains by learning what they do not know in terms of the readers, the informative and educational news in local newspapers contributed to the co-development of the city and the people at the same time. Participants who did not find it sufficient expressed their opinion that the news was superficial and not in depth.

When asked "What kind of educational information in local newspapers do you think gives you a lifelong learning experience? Also, what are their contributions to your learning process in life? Please explain", the participants stated that the informing and educating news they read gave lifelong experience and contributed to their lifelong learning by teaching what they do not know thanks to the different kinds of news they read. A small number of respondents who commented that they did not earn experience stated that the reason for this was that local 
newspapers also had a large number of advertisement pages and gave superficial news.

When asked "Do you share the information and news you learn from local newspapers with your family and friends? What news do you share the most?", the participants indicated that they always shared the important and necessary information they read in local newspapers with their families and their circles. They reported that the news they shared the most were health, education, socio-cultural, labor and employment news. Vasterman, Yzermans, and Dirkzwager [19] found that newspapers helped by educating people about health problems and other problems after disasters and by communicating with people and publishing everything in the region with accurate information.

The research has reached the conclusion that local newspapers can contribute to the lifelong learning of the readers with limited opportunities and by accessing public institutions and employees even at the point of insufficient education, health, environment, socio-cultural life, employment and labor news.

\section{Recommendations}

Local newspapers in the Bartin province can be informed about this research and its results and how important they are in the lifelong learning dimension. More research can be done on formal and intentional uninformed learning that is naturally involved in everyday life, which is an important part of the concept of lifelong learning. Local newspapers can have more room for education, seminars, conferences, and educational articles. In local newspapers, accurate news may be given by the authorities and persons concerned especially on preventive health news. Socio-cultural and environmental news and especially nature news can be compiled in local newspapers and delivered to the readers in the form of documentaries. In local newspapers, news that is much more useful, in-depth and realistic can be published rather than political-oriented and advertisement-intensive news pages. Local newspapers can provide more timely information on labor and employment, the topics for which lifelong learning is thought to be useful. Research on different groups can be done in different regions where the contributions of local newspapers to their readers can be evaluated.

\section{REFERENCES}

[1] Akyüz, M. (2009). Konya Vilayet Gazetesi. Yayımlanmamış Yüksek Lisans Tezi, Selçuk Üniversitesi Sosyal Bilimler Enstitüsü Gazetecilik Anabilim Dalı, Konya.

[2] Asrak, Hasdemir, T. (2012). Geleneksel yeni medya okuryazarlığına: Türkiye örneğinde bir değerlendirme. Hitit
Üniversitesi Sosyal Bilimler Enstitüsü Dergisi. 5 (2), 23-40.

[3] Bilir, M. (2013). Yetişkin eğitiminin tarihsel gelişimi. (Ed. A.Yıldız ve M.Uysal). Yetişkin Eğitimi. (2.Basım). 25-83.İstanbul: Kalkedon Yayınc1lık.

[4] Boffo, V. (2014). From the Memorandum of Lifelong Learning to the Agenda for Adult Learning Winter School/Erasmus Intensive Programme 2014 Comparative Studies International and European Strategies of Lifelong Learning. [Üniversita DelgiStudi Frenze www.lifelonglearning.uni-wuerzburg.de/..._/1]. 1.5.2016.

[5] Brody, M., Bangert ve A., Dillon, J. (2015). "Assessing Learning in Informal Science Contexts" Commissioned paper by the National Research Council for Science Learning in Informal Environments Committee [http://sites.nationalacademies.org/cs/groups/dbassesite/doc uments/webpage/dbasse_080082.pdf]. 18.05.2015.

[6] Büyükbaykal, G., N. (2005). Türkiye'de yerel basının işlevi ve önemi. İstanbul Üniversitesi Illetişim Fakültesi Dergisi. 23.

[7] Büyüköztürk, Ş., Kılıç Çakmak, E., Akgün, Ö.E., Karadeniz, Ş. ve Demirel, F. (2014). Bilimsel araştırma yöntemleri. Ankara: Pegem Akademi Yayınları.

[8] Colardyn, D. (2001). Lifelong learning: which ways forward? College of Europe, 61.

[9] Colardyn, D. \& Bjornavold, J. (2004). Validation of Formal, Non-Formal and Informal Learning: policy and practices in EU Member States European Journal of Education, 39 (1), 71.

[http://www.competences.info/doc/2006_01_12_en_Colard yn_Bjornavold_Validation_formal_non formal_informal_learning.p.pdf] 18.05.2015.

[10] Creswell, J.W. ve Plano Clark V.L. (2015). Karma yöntem araştırmaları tasarımı ve yürütülmesi. (2.Baskı). (Çev. Dede, Y., Demir, S.B.). Ankara: Anı Yayıncılık.

[11] Karasar, N. (2014). Bilimsel araştırma yöntemi (26. Basım). Ankara: Nobel Yayın Dağıtım.

[12] Kaptan, S. (1998). Bilimsel araştırma ve istatistik teknikleri. (11.Baskı). Ankara: Yazıt Dağıtım

[13] MacDonald, M., Hoffman-Goetz, L.(2001). Cancer Coverage in Newspapers Serving Large and SmallCommunities in Ontario. Revue Canadienne De Santé Publique, 92 (5), 372-375.

[14] Merriam, S.B. (2013). Yetişkin eğitimi, kuramdan uygulamaya. (Ed. A.Yıldı ve M.Uysal). Yetişkin Eğitimi. (2.Basım). 105-126. İstanbul: Kalkedon Yayınc1lık.

[15] Miser, R. (2013) Yerel toplulukların eğitimi. (Ed. A.Y1ldız ve M.Uysal). Yetişkin Eğitimi.(2.Basım). 273-285. İstanbul: Kalkedon Yayınc1lik.

[16] Schönbach, K., De Waal, E., Lauf, E. (2005). Online and Print Newspapers: Their Impact on the Extent of the Perceived Public Agenda. European Journal of Communication, 20, 245-258.

[17] Soran, H., Akkoyunlu, B. ve Kavak, Y. (2006). Yaşam boyu ögrenme becerileri ve eğiticilerin eğitimi programı: Hacettepe üniversitesi örneği. H.Ü. Eğitim Fakültesi Dergisi 
(H.U. Journal of Education), 30, 201-210.

[18] UNESCO. (2013). Glossary of Curriculum Terminology. International Bureau of Education. 16-19-26-29.

[19] Vasterman, P., Yzermans, C., J. Dirkzwager, A.,J., E. (2004). The Role of the Media and Media Hypes in the Aftermath of Disasters
Journals
Health.Epidemiologic Reviews, 27 (1), 107-114.

[20] Vural, A., M. (2001). Toplumsal gelişim sürecine katk sağlayan bir araç olarak yerel medya. İstanbul Üniversitesi İletişim Fakültesi Dergisi, 11, 123.

[21] Yıldırım, A.ve Şimşek, H. (2013). Sosyal bilimlerde nitel araştırma yöntemler (9.basım).Ankara: Seçkin Yayıncılık.

*This work was developed and presented using a part of the unpublished postgraduate thesis titled "Evaluation of Contribution of Local Journalists to Lifelong Learning (Example of Bartın Province)". 